\title{
DECISIVE FACTORS IN CHOICE OF TECHNICAL EDUCATION AND PUPILS' PERCEPTION OF TECHNICAL STUDY FIELDS
}

\author{
Petr HLA ĎO - Jiří BALCAR
}

\begin{abstract}
Statistics have been showing a long-term lack of pupils' interest in technical fields of study and secondary schools. Lower-secondary schools have to respond to this situation. Surveys conducted in the Czech environment show that the lack of interest stems not only from individual preferences of students but also from unfavourable image of technical study fields and insufficient or distorted information. The prime objective of this article is to present up-to-date information about primary career choice of pupils, specifically, how pupils perceive technical study fields, which factors influence the choice of these fields, the extent of their autonomy in the decesion-making process and make the educational work of teachers more effective in order to motivate school leavers to technical education.
\end{abstract}

Key words: career choice, secondary school choice, career decision-making, secondary school, study field, technical education.

\section{FAKTORY OVLIVŇUJÍCÍ VOLBU TECHNICKÉHO VZDĚLÁVÁNÍ A PERCEPCE TECHNICKÝCH OBORŮ ŽÁKY ZÁKLADNÍCH ŠKOL}

Resumé: Statistiky vykazuji dlouhodobý nezájem žáků o studium technických oborů vzdèlání a střednich škol. Na tuto situaci musí reagovat základni školy, nebot' výzkumy realizované v českém prostředí ukazuji, že je zapřičiněn nejenom individuálnimi preferencemi žákio, ale i nepř́znivou image technických obori̊ a vlivem nedostatečných či zkreslených informací. Cílem príspěvku je přinést aktuálni poznatky o prvotni volbě povoláni žáků, konkrétně jak žáci vnimaji technické obory, které faktory ovlivn̆uji volbu technicky orientovaných oborů vzděláni a střednich škol a jaká je míra jejich autonomie v rozhodovacím procesu, a tím zefektivnit výchovně-vzdělávací práci učitelů směrem $k$ vy̌šsi motivaci absolventů základnich škol k technickému vzdělávání.

Klíčová slova: volba povoláni, volba středni školy, kariérové rozhodování, středni škola, obor vzdèlání, technické vzdèlávání.

\section{1 Úvod}

Konec 20. a počátek 21. století představují období velkých změn na trhu práce, především ve struktuře zaměstnanosti a $\mathrm{v}$ růstu požadavků na dobře připravené lidské zdroje. Hlavním faktorem zaměstnanosti se stávají znalosti, informace, učení a schopnost lidí je získávat a využívat.

Jaké postavení má v dnešní postindustriální společnosti technické vzdělání? V obecné rovině lze konstatovat, že na základních školách dochází ke snižování počtu vyučovacích hodin technicky zaměřených předmětů (srov. Jeřábek, Tupý, 2005; Vzdělávací, 1998) a tím k poklesu motivace žáků ke studiu analogických oborů na stř̌edních a následně vysokých školách. Jak upozorňuje F. Holešovský (2009), současný systém technického vzdělávání v České republice je navíc poměrně široký a nefunkční. Nefunkčnost systému vychází z toho, že není vytvořena žádná koncepce ani strategie vzdělávání, která by reagovala na měnící se společenské potřeby.

$\mathrm{V}$ následujících letech lze přitom očekávat zvýšení poptávky po zaměstnancích se vzděláním $\mathrm{v}$ technických a př́buzných oborech (srov. Akční, 2008). Jestliže zhodnotíme předpoklady vývoje trhu práce $\mathrm{z}$ pohledu zaměstnavatelů, pak lze říci, že mezi perspektivní obory vzdělání patří řemesla, stavebnictví, strojírenství, informační technologie, elektrotechnika aj. (srov. Burdová, Paterová, 2009).

\section{Implikace pro pedagogickou praxi}

$\mathrm{Na}$ dlouhodobě nízký zájem žáků o studium technických oborů musí reagovat základní školy, nebot' výzkumy realizované v českém prostředí ukazují, že je zapříčiněn nejenom individuálními preferencemi žáků, ale také nepř́íznivou image technických oborů a vlivem nedostatečných či zkreslených informací o technických profesích (srov. Důvody, 2009). 
Nezastupitelnou úlohu při př́pravě žáků na volbu střední školy mají technicky orientované vyučovací předměty, které dávají žákům možnost poznat své vlohy, schopnosti, zájmy a další atributy ve vazbě na technická povolání, seznámit je s obsahem a podstatou řady technických profesí, a to nejenom po stránce teoretické, ale i prostřednictvím praktických činností s technikou (srov. Dostál, 2008; Friedmann, 2006).

Ke zefektivnění výchovně-vzdělávací práce a motivaci absolventů základních škol ke studiu technických oborů a středních škol musí učitelé získat aktuální informace o volbě povolání žáků. Cílem předkládaného př́spěvku je seznámit s dílčími výsledky výzkumu, konkrétně popsat percepci technických oborů žáky 9. ročníků základních škol, definovat faktory působící na volbu technicky orientovaných oborů vzdělání a středních škol a určit míru autonomie žáků při rozhodování o oborové profilaci.

\section{Metodologie empirického šetření}

Empirické šetření bylo založeno na smíšeném výzkumném designu se sekvenčním kombinováním.

V první fázi byla použita kvalitativní metodologie. Zvolenou výzkumnou technikou byly retrospektivní rozhovory vedené $\mathrm{s} 12$ studenty 1. ročníku technických oborů vzdělání (dopravní, telekomunikační, elektrotechnické, chemické, stavební aj.) na středních odborných školách v okrese Ostrava. Sběr dat proběhl v záŕí a říjnu 2009.

Na první fázi navázalo kvantitativní šetření. Výzkumnou technikou byl dotaznik, jenž byl sestaven na základě provedeného kvalitativního šetření, studia odborné literatury a empirických studií. Sběr dat byl uskutečněn $\mathrm{v}$ dubnu a květnu 2010 na základních školách v okrese Ostrava u žáků 9. tř́́d. Do realizace dotazníkového šetření se zapojilo 51 základních škol s počtem 1526 respondentů (velikost výběrového vzorku odpovídá 63,3\% základního souboru). Závěry, prezentované $\mathrm{v}$ následujícím textu, vycházejí z dat získaných od žáků $(n=591)$, kteří v prvním kole přijímacího řízení na střední školy preferovali technické obory vzdělání (KKOV 1-3). Pro srovnání jsou u vybraných kategorií uvedeny poznatky o žácích $(\mathrm{n}=855)$ s preferencí humanitních oborů vzdělání (KKOV 6-8).

Podrobné poznatky z výzkumu jsou dostupné v publikaci Zvolil jsem si techniku. Proč? autorů J. Balcara, J. Havleny a P. Hlad'o (2011).

\section{Důvody ovlivňující volbu oboru vzdělání a stř̌ední školy}

Rozhodování o oboru vzdělání a střední škole je prvním významným krokem směrem $\mathrm{k}$ profesní profilaci jedince a promítá se $\mathrm{v}$ něm řada faktorů a subjektivních kritérií (srov. Walterová, Greger et al., 2009; Trhlíková, Vojtěch, Úlovcová, 2008; Smetáčková, 2005 aj.).

V této části se podrobněji zaměříme na proces volby technického oboru vzdělání a střední školy a důvody, které žáci uvádějí jako podstatné pro výběr svého profesního směřování.

Žáci byli $\mathrm{v}$ dotazníku požádáni o uvedení třech nejvýznamnějších důvodů, které je v prvním kole přijímacího řízení vedly $\mathrm{k}$ volbě technicky orientovaného oboru vzdělání a stř̌ední školy. Kromě obecných životních aspirací typu „chci v životě něco dokázat" nebo „chci, aby na mě byli rodiče hrdi' " bylo možno identifikovat několik konkrétních odůvodnění výběru technického oboru vzdělání a školy. Odpovědi v agregované podobě uvádí následující přehled:

- záliba $\mathrm{v}$ daném oboru a zájem vykonávat povolání spojené s tímto oborem $(56,3 \%)$;

- dobré pracovní uplatnění, př́znivé finanční ohodnocení práce a př́jemné pracovní prostředí $(14,7 \%)$;

- pověst a kvalita konkrétní školy $(5,3 \%)$;

- dosažení určité úrovně vzdělání (4,2 \%);

- nedostatečné studijní výsledky a nenáročnost studia $(4,0 \%)$;

- blízkost školy a bydliště $(4,0 \%)$;

- přátelé $(3,5 \%)$;

- doporučení či tlak rodičů a blízkých osob $(3,5 \%)$;

- následování vzoru z rodiny $(2,4 \%)$;

- osobní předpoklady $(2,4 \%)$.

Nejvýznamnějším důvodem pro volbu technického oboru vzdělání a střední školy jsou individuální preference žáků, resp. záliba v daném oboru a zájem vykonávat povolání spojené s tímto oborem. „Baví mě si hrát s elektřinou “, „zajímám se o auta“.

$\mathrm{V}$ rozhovorech většina žáků 1 . ročníků technicky orientovaných středních škol uvedla, že se o obory, které v současné době studují, zajímají již delší dobu nebo že mají koničky, které nějakým způsobem $\mathrm{s}$ technikou souvisejí. „Jako malý jsem stavél lego, to mé bavilo", „,doma kreslím mosty“, ,, déda je elektrikář, hrál jsem si u něho $v$ dílně s př́stroji“, „s počítačem dělám od 2. třídy základni školy“, „o auta se zajímám od deseti let". 
Tyto aktivity postupně vedly k osvojení znalostí a dovedností, které přssahují kompetence absolventů základních škol, přičemž konkrétně se jednalo o sestavování běžných elektrických obvodů, softwarové ladění výkonu počítače, programování, airbrush automobilů, pokročilou tvorbu webových stránek aj. V těchto prípadech byla volba studijního oboru žáka vyhraněná.

Zájem o určitý obor vzdělání byl u žáků spojen s možností se s ním bližze seznámit a vytvořit si o něm konkrétnější představu, at' již prostřednictvím vlastní zkušenosti nebo jeho vykonáváním v rodině či sociálním okolí. Tyto vlivy působí jak na představy o povoláních, tak na profesní aspirace, vnímání požadavků povolání a posuzování vlastních předpokladů k jejich vykonávání (srov. Giannanto, Hurley-Hanson, 2006).

U žáků volících technické obory bylo možno $\mathrm{v}$ rozhovorech sledovat technické preference také prostřednictvím obliby vyučovacích předmětu na základní škole. Mezi oblíbenými předměty dominovala matematika, fyzika, chemie a částečně také biologie, ačkoliv ne vždy byli učitelé těchto předmětů hodnoceni jako skvělí či alespoň vyhovující.

Na reprezentativním vzorku žáků se potvrdily významné rozdíly mezi technicky a humanitně orientovanými žáky $\mathrm{v}$ př́ípadě obliby fyziky, cizích jazyků a českého jazyka. Tento závěr potvrzuje korelační analýza, která ukazuje, že technicky orientovaní žáci, ve srovnání s humanitně orientovanými, projevují výrazně větší zájem o fyziku $\left(\mathrm{r}_{\mathrm{p}}=0,18 ; \alpha=0,01\right.$; $\mathrm{n}=1498$ ), výrazně menší zájem o cizí jazyk $\left(\mathrm{r}_{\mathrm{p}}=0,17 ; \alpha=0,01 ; \mathrm{n}=1505\right)$ a taktéž menši zájem o český jazyk $\left(r_{p}=0,25 ; \alpha=0,01\right.$; $\mathrm{n}=1502$ ).

Technická orientace byla zřejmá také z výčtu oborů vzdělání, které byly při konečné volbě brány $\mathrm{v}$ úvahu, nebot' téměř vždy se jednalo o obory technického zaměření (napřr. stavebnictví, strojírenství, informatika nebo strojírenství, chemie, elektrotechnika). Technický obor však $\mathrm{v}$ některých př́padech sloužil jako „přestupní stanice“ na cestě za preferovaným povoláním, což se např́íklad projevilo u žáka se zájmem o studium veterinářství, nebot' si podal přihlášku na střední odbornou školu chemickou, kterou vnímal jako adekvátní př́pravu na vysokoškolské studium veterinárního oboru.

Vliv zájmů na volbu povolání, úspěšnost a spokojenost člověka popisují teorie kariérového vývoje. Na konci základní školy se žáci nacházejí v obdobi pokusné volby (srov. Ginzberg et al.,
1951), pro něž je charakteristické seznamování se s požadavky profesí. Žáci se pokouší o volbu povolání na základě sebepoznávání a sebehodnocení. Neberou ještě dostatečně v úvahu objektivní požadavky společnosti a světa práce, rozhodujícími faktory jsou zájmy, osobnostní předpoklady pro výkon zvoleného povolání a hodnoty.

Jsou-li zájmy jasně vyhraněné, má člověk daleko lepší představu o tom, co by chtěl $v$ dalších letech dělat, ale i šance uspět ve zvoleném vzdělávání a profesi jsou vyšší. Podle A. Mezery (2002) mají zájmy prokazatelný vliv na spokojenost člověka ve škole a následně v povolání.

$\mathrm{Z}$ ontogenetického hlediska je třeba upozornit na riziko volby povolání založené výhradně na kategorii zájmů. Je prokázáno, že žáci na konci základní školy často střídají své zájmy, zajímají se o velké množství odlišných oborů, směrů a činností, aniž by si dokázali vytyčit hlavní priority (srov. Jepsen, Dickson, 2003). Silný důraz je přitom kladen na přítomné zájmy a zcela absentuje anticipace jejich možného vývoje po ukončení základní školy (srov. Hlad’o, 2009). Důsledkem je, že se žáci na konci povinné školní docházky poměrně často nerozhodují optimálně, brzy prricházejí na to, že jejich volba nebyla správná a v řadě př́padů jsou nuceni provést reorientaci. Toto potvrzuje i skutečnost, že podíl středoškoláků, kteří zůstávají po absolvování školy ve svém oboru, klesá (srov. Kř́žová et al., 2008). Poznání zájmů, tedy toho, co člověka přitahuje a co ho baví dělat, je proto jednou ze základních podmínek úspěšné volby povolání.

Individuální preference žáků byly následovány dobrým pracovním uplatněním, příznivým finančním ohodnocením práce a prŕijemným pracovním prostředím $(14,7 \%)$. „,Uplatněni do budoucna“, „, auta budou bourat pořád “" , ,je to dobře placená práce “, „čekám od toho šanci v životě".

Při zvažování těchto kategorií jsou důležité znalosti trhu práce a povolání. Významnou úlohu zde sehrává systematická příprava žáků na volbu povolání realizovaná $\mathrm{v}$ rámci formálního kurikula. V předmětech technického charakteru by žáci měli získat přehled o atributech technických povolání, tj. pracovních činnostech, prostředcích a objektech, pracovním prostředí, pracovních požadavcích a možnostech uplatnění na trhu práce.

$\mathrm{Na}$ třetím místě se umístila pověst a kvalita konkrétní školy (5,3\%). „Zaujaly mě práce studentù dané školy“, ,zaujalo mě to na dnu 
otevřených dveří", „vyhlášená škola“, „vybaveni školy".

Analýza kvalitativních dat $\mathrm{z}$ rozhovorů ukázala, že hodnocení pověsti a kvality školy ovlivňují především starší přátelé žáků, popř. jejich sourozenci, kteří mají se střední školou osobní zkušenost $\mathrm{z}$ pozice studenta a mohou o ní podat velmi podrobné informace. Sociální styk s vrstevníky funguje jako velmi důležitý informační kanál při získávání informací významných pro rozhodování. Starší kamarádi a sourozenci zprostředkovávají žákům subjektivní hodnocení pedagogického sboru a jeho úrovně, školního kurikula, klimatu školy a další informace.

Neméně významné jsou návštěvy dnů otevřených dveří na školách. Žáci při nich hodnotí vlastní pocity $\mathrm{z}$ budovy a vnitřních prostor školy, vybavení, celkové atmosféry a pedagogických pracovníků. Zajímavou skutečností, která je žáky ve vztahu k návštěvám dnů otevřených dveří poměrně často uváděna, je možnost promluvit si př́mo se studenty školy a získat od nich informace.

Do rozhodování žáků se odrážejí i vzdělanostní aspirace, nebot' $4,2 \%$ respondentů uvedlo, že si technický obor vzdělání a školu zvolilo kvůli dosažení určité úrovně vzdělání. „Je to škola s maturitou“, „,chci jit studovat na vysokou“.

Volba maturitního vzdělání na střední odborné škole umožňuje podle J. Trhlíkové a I. Eliášové (2009) získat tzv. dvojí kvalifikaci, je př́pravou jak pro prímý vstup na trh práce, tak i do terciárního vzdělávání. Představuje proto vhodnou volbu pro ty, kteří mají relativně vyhraněné zájmy, ale nejsou si jisti, zda budou pokračovat ve studiu na vysoké škole.

Zatímco uvedené důvody působily ve směru pozitivní motivace, z výsledků šetření je zřejmý i vliv limitujících faktorů. Těmi jsou nedostatečné studijní výsledky, které uvedlo 4,0\% dotázaných žáků. „, Jsem ráda, že mě někde vzali“, ,, nemám na lepší", ,lehká škola“.

Tato kategorie úzce souvisí s požadavky přijímacího řízení. $\mathrm{Na}$ většině středních odborných škol žáci nevykonávají přijímací zkoušky, ale jsou přijímání na základě průměrného prospěchu. P. Hlad'o (2009) zjistil, že žáci a rodiče mají již $\mathrm{v}$ době před podáváním přihlášek předběžné informace o požadavcích na průměrný prospěch. Pokud uchazeč stanovených požadavků nedosahuje, dopředu ví, že podat si přihlášku na tento obor či školu představuje značné riziko a vysokou pravděpodobnost neúspěchu při přijímacím řízení.

Ze zjištěných důvodů je nezbytné zmínit i doporučení či tlak rodičů a blízkých osob $(3,5 \%)$ a následování vzoru z rodiny $(2,4 \%)$. „Dohoda s matkou“, „,rodiče si to prejï“, „,dèlá to celá rodina ", ,jdu ve stopách svého otce ".

Řada českých i zahraničních výzkumů potvrdila, že volba povolání žáků je formována přímým i nepřímým působením rodičů a rodiny. Vliv má jak rodinné prostředí, tak rodinné procesy (srov. Hlad'o, 2010). Zajímavé jsou zjištěné rozdíly v zapojení rodičů do volby oboru vzdělání mezi žáky, kteří volili technický (KKOV 1-3) a humanitní obor vzdělání (KKOV 6-8). Podíl respondentů, u nichž rodiče tvořili poradní hlas, je stejný bez ohledu na preferované zaměření oboru. U technických oborů však lze identifikovat výrazně větší počet žáků volících samostatně, bez pomoci rodičů, zatímco u žáků volících humanitně zaměřené obory lze identifikovat častější tvorbu kompromisů mezi přáním žáka a rodičù. Tento vztah, ačkoli není ve svém rozsahu výrazný, potvrzuje provedená korelační analýza $\left(r_{p}=0,06 ; \alpha=0,01 ; n=1438\right)$.

\section{Konotace pojmu technický obor}

V kvalitativním výzkumu s názvem Di̊vody nezájmu žáků o prírodovédné a technické obory (Důvody, 2009) bylo rozhovory s výchovnými poradci zjištěno, že žáci na základních školách některé technické obory hodnotí jako „špinavé“, „fyzicky náročné“, „,namáhavé“. V kontrastu s tím považují za ideální povolání „čistou“ a „nenáročnou“ práci $\mathrm{v}$ kanceláři, $\mathrm{s}$ počítačem. $\mathrm{Z}$ dotazníkového šetření mezi studenty čtyřletého $(\mathrm{n}=515)$ a víceletého gymnázia $(\mathrm{n}=414)$ byl ve jmenované studii formulován profil technických oborů, jehož čtyřmi nejvýraznějšími atributy jsou: obtížný, mužský, praktický, perspektivní.

Společně se základními faktory, jež se promítají do volby technického oboru vzdělání a střední školy, proto považujeme za důležité vymezit, jaké charakteristiky spojují absolventi základních škol s technickými obory. Otevřenými otázkami byly $\mathrm{v}$ dotazníku zkoumány pozitivní a negativní konotace pojmu „technický obor", přičemž respondenti měli možnost uvést maximálně trri pozitivní a tři negativní konotace.

Zajímavým zjištěním je, že nejčastější pozitivní i negativní konotace pojmu „technický obor“ jsou mezi žáky s technickým i humanitním zaměřením stejné. Mezi nejčastěji zmiňovaná pozitiva technických oborů patří dobré uplatnění na trhu práce $(21,6 \%$ technicky 
orientovaní vs. $35,7 \%$ humanitně orientovaní žáci) a př́íznivé finanční ohodnocení práce $(18,9$ $\%$ vs. $14,8 \%$ ). Technicky orientovaní žáci mezi pozitivy dále uvádějí práci s technikou $(14,8 \%)$, zatímco humanitně orientovaní žáci uvádějí nižší nároky na přijetí ke studiu technického oboru 9,5 $\%)$.

$\mathrm{V}$ př́ípadě negativ technických oborů se obě skupiny žáků shodují na náročnosti a fyzické namáhavosti práce $35,0 \%$ vs. 30,3 \%), nebezpečnosti práce, nepříznivém pracovním prostředí $(29,9 \%$ vs. $21,3 \%)$ a na náročné př́ípravě na povolání $(24,1 \%$ vs. $19,6 \%)$. Technicky orientovaní žáci mezi negativa dále zařadili nepříznivé finanční ohodnocení práce $(5,3 \%)$ a humanitně orientovaní žáci skutečnost, že se jedná o typicky mužská povolání $(8,6 \%)$, nezajímavou nebo nudnou práci $(8,6 \%)$ s nepř́iznivým finančním ohodnocením $(8,2 \%)$ a horším pracovním uplatněním na trhu práce $(3,4 \%)$.

Př́nosné je poznání hodnocení technických oborů žáky základních škol volícími humanitně orientované studijní obory, nebot' jejich volba může být $\mathrm{v}$ některých př́padech způsobena zkresleným vnímáním technických oborů, což v praxi znamená ztrátu potenciálních uchazečů ze strany technických středních škol.

Z jednotlivých výpovědí žáků volících humanitně zaměřené obory vyplývá, že až na několik jedinců, kteří technické obory vnímají jako obory vysoce sofistikované, zabývající se „,nevšedními věcmi“, jsou technické obory spojovány spíše s výkonem méně kvalifikované, manuální a monotónní práce dělnického charakteru. Tento typ povolání je, podle převažujícího přesvědčení žákủ, vykonáván méně bystrými osobami, většinou muži, nebot' tyto práce vyžadují fyzickou sílu a dále manuální zručnost. Této představě pracovníka analogicky odpovídá prredstava pracovního prostředí, které je vnímáno jako nepříznivé (prach, hluk, zima nebo horko, práce venku apod.) s možností vzniku pracovního úrazu. Negativní skutečnosti jsou kompenzovány relativně vysokými mzdami a dobrým pracovním uplatněním na trhu práce, spolu s využitelností získaných kompetencí v osobním životě. Kvalifikace „technikư“ je však žáky volícími humanitní vzdělání často vnímána jako velmi úzká, tj. s velmi omezenou pracovní mobilitou, což podle jejich názoru ústí ve vysoké riziko nezaměstnanosti $\mathrm{v}$ případě strukturálních změn.

Humanitně orientovaní žáci vnímají volbu technického oboru prevážně jako nedostatečně prestižní záležitost, vhodnou pouze pro žáky s horšími studijními výsledky, jimž odpovídají nižší nároky na přijetí na tento typ oborů vzdělání. Představa humanitně orientovaných žáků posledních ročníků základních škol v okrese Ostrava o obsahu výrazu „technický obor“" stále ještě odpovídá spíše představě dělníka $\mathrm{v}$ hutním provozu než vědeckého pracovníka $\mathrm{v}$ oblasti materiálového výzkumu či architekta navrhujícího impozantní stavby. Žáci, kteří naopak vnímají technické obory jako vysoce sofistikované a prestiž technických povolání srovnatelnou s prestiží povolání humanitních, se naopak obávají studia matematiky a fyziky, které vzhledem ke svému zaměření a svým preferencím vnímají jako extrémně obtížné a tvořící tak nepřekročitelnou bariéru.

\section{Závěr}

Výběr oborů vzdělání a střední školy je vícekriteriálním rozhodováním postaveném na objektivních, ale i subjektivních informacích. Rozhodování žáci činí na základě kompromisů mezi osobními hodnotami, přáními, cíli, zájmy, schopnostmi, vnějšími podmínkami sféry vzdělávání a světa práce. Jeho průběh i konečná podobu je ve velké míře ovlivněna působením rodičů a blízkého sociálního okolí, ale i ontogenetickými charakteristikami pubescence.

Prezentované poznatky ukazují na prostor pro zvyšování zájmu žákủ o technické obory a střední školy v rámci formálního vzdělávání na základních školách. Významné možnosti skýtají jak vyučovací předměty technického charakteru, tak předměty participující na výuce tematického okruhu Svět práce. Učitelé v nich mohou rozvíjet schopnosti a zájmy žáků, poskytovat kvalifikované informace o oborech vzdělání, náplni a perspektivách jednotlivých profesí, a tím motivovat $\mathrm{k}$ volbě oboru, který bude nejvíce odpovídat individuálním preferencím a předpokladům žáka (srov. Friedmann, 2006). Jejich potenciál zahrnuje i rozvoj sebepoznávání, utváření a rozvíjení praktických dovedností a žádoucích osobních vlastností žáků, které jsou důležité při rozhodování o významných životních krocích, při plánování budoucnosti a začleňování do pracovního života.

Závěrem lze konstatovat, že žáci, vzhledem k poměrně vysoké míře autonomie, při volbě povolání fakticky potřebují intenzivní prípravu a systematické vedení, které by měly vést $\mathrm{k}$ samostatnému a zodpovědnému rozhodnutí. 


\section{Literatura}

[1]Akčni plán podpory odborného vzdělávání. Praha : MŚMT, 2008. $131 \mathrm{s.}$

[2] BALCAR, J., HAVLENA, J., HLAĎO, P. Zvolil jsem si techniku. Proč? Brno : Mendelova univerzita v Brně, 2011. ISBN 978-80-7375-484$6 . \quad$ Dostupný $\quad z$ WWW: $<$ http://resa.rza.cz/www/file.php?id=79>.

[3] BURDOVÁ, J., PATEROVÁ, P. Potřeby zaměstnavatelù a pripravenost absolventů škol šetřeni v zemédělské sfére. Praha : NúOV, 2009. $27 \mathrm{~s}$.

[4]DOSTÁL, J. Výchova k volbě povolání. In Trendy ve vzdélávání. Olomouc: Votobia, 2008, s. 50-53. ISBN 978-80-7220-311-6.

[5]Di̊vody nezájmu žáků o přirodovédné a technické obory: výzkumná zpráva [online]. c2009, poslední revize 18. 8. 2009 [cit. 2011-0105]. Dostupný $\mathrm{z}$ WWW: <http://ipn.msmt. cz/data/uploads/portal/Duvody_nezajmu_zaku_o _PTO.pdf>.

[6] FRIEDMANN, Z. Profesní orientace žáků. In STŘELEC, S. (ed.). Studie z teorie a metodiky výchovy II. Brno : Masarykova univerzita, 2006, s. 165-177. ISBN 80-210-3687-7.

[7] GIANNANTONIO, C. M., HURLEYHANSON, A. E. Applying Image Norms Across Super's Career Development Stages. Career Development Quarterly, 2006, Vol. 54, No. 4, pp. 318-330. ISSN 0889-4019.

[8] GINZBERG, E., et al. Occupational Choice : An Approach to a General Theory. New York : Columbia University Press, 1951. 271 p. ISBN 978-0-2310-1846-3.

[9]HLAĎO, P. Volba další vzdělávací dráhy žáků základních škol v kontextu rodiny: disertační práce. Brno : MU, Pedagogická fakulta, 2009. 2301.

[10] HLAĎO, P. Vliv sociálního okolí na kariérové rozhodování žáků při přechodu do vyššího sekundárního vzdělávání. Pedagogická orientace, 2010 , roč. 20 , č. 3 , s. 66-81. ISSN 1211-4669.

[11] HOLEŠOVSKÝ, F. Technické vzdělání jako služba společnosti. Technický týdenik, 2009, roč. 59, č. 14. ISSN 0040-1064.

[12] JEPSEN, D. A., DICKSON, G. L. Continuity of Life-Span Career Development. Career Development Quarterly. 2003, Vol. 51, No. 3, pp. 217-233. ISSN 0889-4019.

[13] JEŘÁBEK, J., TUPÝ, J. Rámcový vzdělávaci program pro základni vzdéláváni s př́lohou upravujicí vzděláváni žáků s lehkým mentálním postižením. Praha : VÚP , 2005. ISBN 80-87000-02-1.

[14] KATRŇÁK, T. Odsouzeni k manuálni práci: vzdělanostní reprodukce $v$ dělnické rodině. Praha : Sociologické nakladatelství, 2004. 190 s. ISBN 80-86429-29-6.

[15] KŘÍŽOVÁ, E., et al. (2008). Přechod absolventů maturitnich oboru SOU do praxe a jejich uplatnění na trhu práce. Praha : NÚOV, 2008. $32 \mathrm{~s}$.

[16] MEZERA, A. Pro jaké povolání se hodim? Praha : Computer Press, 2002. 178 s. ISBN 80-7226-651-9.

[17] SMETÁČKOVÁ, I. (ed.). Genderové aspekty prechodu žáků a žákyn̆ mezi vzdělávacími stupni. Praha : Sociologický ústav AV ČR, 2005. $233 \mathrm{~s}$.

[18] TRHLÍKOVÁ, J., ELIÁŠOVÁ, I. Volba střední školy a kariérové poradenství. In WALTEROVÁ, E., GREGER, D., et al. Přechod žákì a žákyn̆ ze základni na středni školu: pohledy z výzkumů. Brno: Paido, 2009, s. 23-47. ISBN 978-80-7315-179-9.

[19] TRHLÍKOVÁ, J., VOJTĚCH, J., ÚLOVCOVÁ, H. Rozhodováni žáků při volbě vzdělávací cesty a úspěšnost vstupu na trh práce. Praha : NÚOV, 2008. $38 \mathrm{~s}$.

[20] Vzdélávaci program Základni škola. Praha : Fortuna, 1998. 336 s. ISBN 80-7168-595$\mathrm{X}$.

[21] WALTEROVÁ, E., GREGER, D., et al. Přechod žáků a žákyn̆ ze základní na střední školu: pohledy z výzkumů. Brno : Paido, 2009. 107 s. ISBN 978-80-7315-179-9.

Přispěvek vznikl za finanční podpory ESF a státního rozpočtu $\check{C} R$ v rámci projektu „Podpora odborného vzdělávání na střednich školách MSK“ (OP VK CZ.1.07./1.1.07/11.0112).

PhDr. Petr Hlad'o, Ph.D.

Institut celoživotního vzdělávání

Mendelova univerzita v Brně

Zemědělská 5

613 00, Brno, ČR

Tel.: +420 545135215

E-mail: hlado@mendelu.cz

Ing. Jiří Balcar, Ph.D.

RPIC-ViP s. r. o.

Výstavní 2224/8

709 01, Ostrava, ČR

Tel.: +420 596626917

E-mail: balcar@rpic-vip.cz 